DOI: 10.2478/RAE-2019-0025 Review of Artistic Education no. 182019 233-240

\title{
3. ART - SUBJECT - OBJECT IN ARTISTIC AND PLASTIC CREATIVITY OF PUPILS AND STUDENTS IN ARTISTIC EDUCATION
}

\author{
Olimpiada Arbuz-Spatari ${ }^{247}$
}

\begin{abstract}
The modernization of higher education in the field of plastic arts methodology, the improvement and development of the educational methodology, as well as the professional rise of the teachers are the key issues in raising the level of creativity of the future plastic art teachers in the context of the new requirements of artistic training. The volume of creative knowledge and skills varies from one person to another; it is our permanent intention to know and understand creativity, to demonstrate the laws of artistic and plastic creativity, to create a logical theory through which personality can be developed creatively, thus contributing to the complex process of the student's artistic activity. Art contributes to the development of the artistic creativity of pupils / students, constituting a source of knowledge of national and universal culture through the many methodological, plastic and technological varieties specific to art, which offer vast possibilities to create a creative product of artistic, aesthetic and cultural value. The development of creative writing skills initially involves a visual experience, followed by the stages specific to the creative process in the field of fine arts and is finalized by a material form of the creative product, obtained through specific means in the field of fine arts.
\end{abstract}

Key words: art, creativity, artistic and plastic creativity, subject-matter, artistic education

\section{Introduction}

In the development of artistic and plastic creativity, a primary role belongs to the creative process itself. The creative process is a specific activity, which involves creative thinking, develops specific skills and attitudes specific to the plastic arts engaged in the examination of the forms of reality and in the selection of the aesthetic tangible ones, turning them into a significant unity of the creative work. The correlation and interaction of training and creative activity processes is of particular interest. That is why we are constantly researching the laws of the development of artistic creativity, we study the methods and forms of organizing the training process and, at the same time, the creative process. Many research in pedagogy is geared towards improving the training process to discover the creative potential of personality.

\section{Discussions}

The plastic work developed in the creative process is the consequence of an experience, obtained by visual perception, of the direct involvement of the creative personality in the activities of study, analysis and discovery of the

\footnotetext{
${ }^{247}$ Associate Professor PhD, "Ion Creanga" State Pedagogical University from Chişinău, Republic of Moldova, email: olimpiada123@mail.ru
} 
visual world; which is the result of an investigation and methodological research; aiming at revealing the relations between the plastic elements, the plastic shapes, the symbols and their significance. From Hegel's philosophical and aesthetic system, we define as meaningful to our research object the definition of aesthetic activity, identifiable with artistic creativity, as the way to freedom (Apud V1.Paslaru, 12, p. 79).

XIXth century. An interesting concept on the concept of creativity expressed a century ago the French esthetician of Romanian origin Şt.Lupaşcu, who demonstrated that in art, thinking is not only a discoverer of laws and principles, as in scientific knowledge, but the field in which truth (artistic) becomes as such. "In other words, according to Vl.Paslaru, the truth (according to Şt.Lupaşcu.- O.A.-S.) is not just what exists a priori and outside the knowledgeable subject; the truth is the becoming of the knowing subject, of the human being. Or, the truth becomes true; it is created by the very human being as truth. "[12, p. 81]. From Stefan Lupascu's conception, we also learn other valuable theses that reveal the essence of creativity, such as:

- unity / Diversity / Complementarity of the subject - object:

- artistic image / creation is both subject and object;

- the origin of the artistic image's freedom in the receptivity and modality of the subject, the factors of influence on the receiver, etc .;

- the ability of the artistic image to be simultaneously real and unreal;

- the dynamic and never sure of the artistic image, being mobile and pluralistic; the image as an inner reality conscious;

- creative imagination as the strongest and most fertile phenomenon specific to psychism; art as a process of knowledge of knowledge, awareness of consciousness;

- the art's tendency for the subject to merge with the object, or vice versa: the subject and subject merge to disappear;

- the ability of creative imagination to release man from the tyranny of the subject (or self) as well as that of the object (the universe);

- the self-sufficiency of imaginative universes - subjective and objective, real and fantastic, true and false, etc .;

- the truth of creative imagination: here everything is true, because everything is possible; and every possibility is true;

- the reversible character of temporality in art and the playful character (it is a toy) of space;

- the quality of the spiritual product of art, resulting from "interference in the biological universe, which mingles in the physical universe, in order to obey both the psychic universe" (= spiritual.-O.A-S); art is not an escape from the real world, but a transfiguration of it;

- conceptual excellence of art work; the imminent character of emotion for art: art without emotion does not exist; affection is a given of being, so art is essential to existence. [Apud V1.Paslaru, 12, p.83-84]. 
The XXth Century marks tremendous developments in classical ancient and modern aesthetics, both on the coordinate of the work, as well as on those of reception and of receiver, which are the components of creativity in art. M. Heidegger appreciates: "The artist is the origin of the work. The opera is the origin of the artist "[6, p.31], develops the thesis already elaborated by Şt.Lupaşcu, that in the work of art the truth is not discovered, but it is created continuously and that this is the receiver that is defined by it as a preservationist and as the second author of the work of art.

\section{Results}

An original aspect of $M$. Heidegger's concept is the thesis on the occurrence of truth in the work of art: it reappears every time the work is received, with new valences, coming from the quality of the receiver [6, p. 76, p. 91 ]. A second great aesthetician of the 20th century is H.R.Jauss, who developed the theory of aesthetic experience, according to which art (literature) is an endless process of aesthetic communication in which the author and receiver of the work come into contact. H.R.Jauss also acquires the receiver with the status of the second (re) creative subject of the work of art, because, he says, it extends its own waiting horizon to the work [7].

Table 1. Researchers and scholars on the concept of art

\begin{tabular}{|c|c|}
\hline C.Radu & $\begin{array}{l}\text { The immanent attributes of art: } \\
\text { - art as the demiurgic dimension of man; } \\
\text { - art as a hypostasis of freedom (Apud V.Maşek); } \\
\text { - art as imagination and reflection; } \\
\text { - art as an active and exploratory attitude; } \\
\text { - art as a factor to strengthen the harmonious unity of the individual, to } \\
\text { maintain the system unit of the world of values. } \\
\text { - formal art (renders objects form, expressive form). }\end{array}$ \\
\hline I.Moraru & $\begin{array}{l}\text { - the definition of creativity as an appropriation of existence; } \\
\text { - typology of creative personality: with low index of creativity, volitive, } \\
\text { cumulative, combinative-volitive, cumulative-combinatory-volitive, } \\
\text { combinative-fabulative, combinative-critical, cumulative-hypercritical, } \\
\text { ideative, ideative-imagistic, imagistic, ideative-imagistic-object }\end{array}$ \\
\hline $\begin{array}{l}\text { Im.Kant, } \\
\text { developed by } \\
\text { W.Tatarki ewicz }\end{array}$ & $\begin{array}{l}\text { Definition of artistic form as: } \\
\text { - provision, order of the parties; } \\
\text { - what is given directly to the senses; } \\
\text { - the boundaries or outline of an object; } \\
\text { - the conceptual essence of an object (Apud Aristotle); } \\
\text { - the intellect's intake at the perception of the object }\end{array}$ \\
\hline N.Kandinsky & Twelve examples of punctual form \\
\hline W.Worringer & $\begin{array}{l}\text { - Form as art of ornamentation; } \\
\text { - syntax of artistic language }\end{array}$ \\
\hline I.Frunzetti & The realistic character of the ornamental motifs in the Romanian folk art \\
\hline L.Blaga & Geometrism of Romanian folk art \\
\hline N.Dunăre & The framing of the Romanian folk art in the contemporary creation \\
\hline Z.Dumitrescu & - Defining the form of plastic art: means of expression and aesthetic \\
\hline
\end{tabular}




\begin{tabular}{|c|c|}
\hline & $\begin{array}{l}\text { communication; } \\
\text { - the notions of plastic language: the point, the line, the surface, the } \\
\text { volume; } \\
\text { - particularities of geometry in Romanian folk art; } \\
\text { - categories of symbols in plastic art. }\end{array}$ \\
\hline D.Mihăilescu & $\begin{array}{l}\text { - defining languages as a form of individual manifestation, as a functional } \\
\text { communication system; } \\
\text { - classification of languages (sound, visual); } \\
\text { - definition of form as raw material, means of expression and aesthetic } \\
\text { communication. }\end{array}$ \\
\hline S. and I. Cibotaru & $\begin{array}{l}\text { - styling as an element specific to the artistic form; } \\
\text { - classification of popular ornamental motifs (abstract, cosmomorphic, } \\
\text { phytomorphic, zoomorphic, anthropomorphic, social) }\end{array}$ \\
\hline I.Şuşală & Initial benchmarks specific textile art \\
\hline $\begin{array}{l}\text { J.Chevalier and } \\
\text { others }\end{array}$ & The symbolic values of artistic language \\
\hline $\begin{array}{l}\text { Dicţionarul de } \\
\text { artă (Dictionary of } \\
\text { art) }-2000\end{array}$ & Plastic language identification with artistic form \\
\hline D.Mureşan & $\begin{array}{l}\text { - Functions of plastic language: fixation, expression, communication, } \\
\text { knowledge and influence and transfer of information; } \\
\text { - PL elements, equivalent to forms in nature } \\
\text { - the connotation of plastic art; }\end{array}$ \\
\hline
\end{tabular}

- The development of artistic creativity takes place within the creative process, which is a specific activity that plenarily involves creative thinking, develops the skills and attitudes specific to the plastic arts engaged in the examination of the forms of reality and in the selection of the aesthetic tangible, turning them into a unit of the creative work.

- As seen from previous conceptualizations, the creative personality is essentially determined by the development of its creative skills, the formation / development / manifestation of specific attitudes for plastic art. The notions of the two essential characteristics of the creative personality are imagination, as the process of reproducing the new by (re) combining the previously acquired information; general intelligence that provides problem solving and problem situations; logical (deterministic) thinking and artistic (reflexive) thinking, which ensures the unity of imagination with the intellect (Kant), designed multiphase based on the information-operational unit, realizable in a convergentdivergent sense; special skills (artistic-aesthetic); general attitudes (affective, motivational, characteristic) and artistic (of reception - creative) attitudes.

- Characteristics of the creative personality in the plastic arts. We considered from the very beginning that the student of plastic art pedagogue is by definition a creative personality in training, an idea endorsed by several authors, including: I. Bontaş [1], L. Cantemir [4, 5], M. Carcea [ 4, 5], V.Dulgheru [4, 5], J.Guilford [Apud 16], H.Gougli [Apud 13], V.Lowenfield [Apud 16], I.Moraru [8, 9] [Apud 13], G. Nagâţ [10], G. Popescu [13], M.Roco [14], A. Roşca [15, 16], 
C.Taylor [Apud 13], M. Zlate [13] from the works of which we synthesized the characteristics of the creative personality, which we present in Table 2 according to the established personality structure:

- Skills (knowledge + capabilities / skills + attitudes) - Characteristic traits Behaviors.

Table 2. Values specific to the creative personality

\begin{tabular}{|c|c|}
\hline \multicolumn{2}{|r|}{ Competencies } \\
\hline $\begin{array}{l}\text { Knowledge. The student } \\
\text { will know / understand: }\end{array}$ & $\begin{array}{l}\text { - genres of decorative art in correlation with other genres of plastic } \\
\text { art; } \\
\text { - compositional principles in textile art works; } \\
\text { - the components and characteristics of elements of artistic } \\
\text { language / artistic form in the fine arts / textile art; } \\
\text { - the role of basic knowledge of decorative art in rendering plastic } \\
\text { symbols of plastic language elements; } \\
\text { - the difference between shapes and lines in creating the abstract } \\
\text { decorative composition; } \\
\text { - the artistic methods and basic techniques for the elaboration of } \\
\text { textile art / art prints; } \\
\text { - the role of pedagogical practice in strengthening the knowledge of } \\
\text { artistic-plastic language / textile art. }\end{array}$ \\
\hline Capabilities / Skills: & $\begin{array}{l}\text { - to develop (J.P.Guilford); } \\
\text { - to adapt quickly to any situation (V. Lowenfeld); } \\
\text { - to design goals in the medium and long term (G. Popescu); } \\
\text { - to form conceptual-action capacities (I.Moraru); } \\
\text { - to anticipate difficult issues (M.Roco) }\end{array}$ \\
\hline Skills: & $\begin{array}{l}\text { - Intellectually systematized (J.P.Guilford). } \\
\text { - Restructuring, analysis, synthesis and coherence of the } \\
\text { organization (V. Lowenfield). } \\
\text { - Visual acuity and manual ability, manifested in skills: } \\
\text { - Fast, accurate and durable fixation of the visual image of objects; } \\
\text { - perception of the whole, with a lower inclination for analysis; } \\
\text { - to correctly assess the vertical or horizontal line deviation; } \\
\text { - Appropriate appreciation or reproduction of the proportion of } \\
\text { objects; } \\
\text { - appreciation or artistic judgment (to distinguish the original copy); } \\
\text { - Drawing; } \\
\text { - fast and accurate fixation of the visual image and objects; } \\
\text { - Rapidly linking processes and ideas; } \\
\text { - operative thinking (G. Popescu). } \\
\text { - Discrimination of spatial aspects (G.Nagâț) }\end{array}$ \\
\hline Attitudes: & $\begin{array}{l}\text { - It is self-defining (J.P.Guilford). } \\
\text { - It is sensitive to problems, phenomena; identifies with the } \\
\text { problems of alterity (of persons and social); manifest variability in } \\
\text { ideas (V. Lowenfeld). } \\
\text { - It is tolerant in ambiguous situations; he trusts in his own creative } \\
\text { capacities; (C. Taylor). } \\
\text { - Manifest attitudes in various cultural contexts and forms of } \\
\text { creation (G. Nagâţ). } \\
\text { - Appears as an artistic type (poet, plastic artist, musician) and as a }\end{array}$ \\
\hline
\end{tabular}




\begin{tabular}{|c|c|}
\hline & $\begin{array}{l}\text { thinker (researcher, inventor); is sensitive to problems that require } \\
\text { original solutions (G. Popescu). } \\
\text { - Interest in new, attraction to difficult problems, attraction to } \\
\text { complexity, self-desire, self-refinement, appreciation of values } \\
\text { (M.Roco) } \\
\text { - It is sensitive to problems, phenomena; identifies with the } \\
\text { problems of alterity (of persons and social); shows variability in } \\
\text { ideas (V. Lowenfeld). } \\
\text { - It is tolerant in ambiguous situations; trusts in his own creative } \\
\text { capacities; (C. Taylor). } \\
\text { - Manifests attitudes in various cultural contexts and forms of } \\
\text { creation (G. Nagât). } \\
\text { - Appears as an artistic type (poet, plastic artist, musician) and as a } \\
\text { thinker (researcher, inventor); is sensitive to problems that require } \\
\text { original solutions (G. Popescu). } \\
\text { - Interest in new, attraction to difficult problems, attraction to } \\
\text { complexity, desire for self-sufficiency, desire for self-refinement, } \\
\text { value appreciation (M.Roco) }\end{array}$ \\
\hline \multicolumn{2}{|r|}{ Character features } \\
\hline \multicolumn{2}{|c|}{$\begin{array}{l}\text { - Sensitivity to problems, sensory sensitivity, responsiveness, mobility (V. Lowenfeld). } \\
\text { - Fluidity, flexibility, originality, elaboration (J.Guilford). } \\
\text { - Inventiveness, uninhibited independence, enthusiastic versatility (M. Zlate). } \\
\text { - Imagination, talent, better development of the right hemisphere - "the seat of artistic } \\
\text { competence" (M.Roco). } \\
\text { - General aesthetics: aesthetic taste, aesthetic judgment, abstract thinking; fluency in ideas, } \\
\text { independence in thinking, active perseverance, self-confidence, the need to produce the new, } \\
\text { fantasy and creative imagination; } \\
\text { - Sensory-motor: observation spirit, visual acuity, sense of light and color, sense of proportion, } \\
\text { rhythm, shape and volume; } \\
\text { - Motric: manual dexterity, good coordination of vision and hearing, accuracy and speed in } \\
\text { hand movements; } \\
\text { - Intellectual: high intelligence (at least medium), rich imagination; } \\
\text { - Affective and motivational: passion for art, sensitivity, perseverance and work power (G. } \\
\text { Popescu). } \\
\text { - Analytical, critical, flexible, commutative, lateral, divergent thinking, prediction intuition, } \\
\text { flair, decisional thinking involved in ingenious problem solving, conceptual intelligence, } \\
\text { creative thinking (intellectual component); } \\
\text { - passion for work and creation, boldness and courage to address problems from the } \\
\text { perspective of the new (the affective-volitional component); } \\
\text { - perceptual intelligence, the sense of seeing / detecting / detecting the new quickly and } \\
\text { precisely, the combined imagination (the perceptive-imaginative component); } \\
\text { - motor intelligence, perseverance in the transposition and application of the new (motor- } \\
\text { action component) (I.Moraru). } \\
\text { - The sense of proportions, rich imagination, empathy, visual and tonal memory (G.Nagât). } \\
\text { - Courage in addressing difficulties and avoiding routines, independence in thinking and } \\
\text { action, non-conformism, perseverance, self-denial tendency (M.Roco) }\end{array}$} \\
\hline \multicolumn{2}{|r|}{ Behaviours } \\
\hline & \\
\hline
\end{tabular}


- Different thinking, artistic thinking (including visual-expressive thinking and abstracttheoretical thinking) (D.Muresan).

- Creative Thinking (Al.Roşca et al.).

- Memory: characteristics (association, capacity, clarity / precision, longevity, selectivity, degree of training) and types (professional, visual) (Dulgheru and others).

- The picture synthesized by Table 2 of the creative personality values demonstrates that the science of this field has not yet established a clear, sufficient epistemic vision of the personality structure of the plastic artist.

- The artistic and aesthetic knowledge specific to the activity in the field of fine arts is not mentioned by any author consulted by us, which is a serious gap in this domain of aesthetics, since they are indicated even by the curricula [2, 3 ].

- The capacities for artistic and plastic activity, although in reality are very large, are mentioned by a few authors and in small numbers.

- The specific skills in the plastic arts are defined by G.Nagât, according to which they supplement the general ones (intellectual, attitudinal, motivational), but alone can not ensure creativity, but only in correlation with intellectual, affective, motivational value etc. In painting, for example, at least an average intellectual coefficient is required, and for a symbolic, analytical or allegorical drawing a much higher coefficient [10].

- Developing specific skills, says G. Popescu, ensures the attainment of the superior levels of creativity, the innovative and the emerging ones [13].

- Creative attitudes in the plastic arts are not rigorously systematized. M.Roco, for example, quoted by G.Popescu, identifies a series of creative attitudes [13, p.128], which, according to Vlad Pâslaru's concept of attitudes [11], are in fact their own manifestations or traits (See Table 2).

- The specific characteristics of the plastic artist, as well as his other values, are not epistemic and are not systematized. However, there are attempts to consider, such as that of G. Popescu, which structures the values of the plastic artist in the sensory-motor skills involved, motor skills, intellectual abilities and affective, motivational and characteristic features (see Table 2).

- The indicated values, although not at all, exhaust the entire axiological spectrum of the personality:

- Creative (eg, the authors have not indicated their special knowledge), points out specific skills, traits and behaviors sufficient to identify a creative person, especially as the singular implicitly includes the general, so a single competence, ability or behavior can identifies an artist.

\section{Conclusions}

The creative personality in the field of fine arts has the same psychic and axiological structure as the common man, but its components are marked by specific values, such as: highly developed visualization mechanisms, conceptualization and re-organization; increased sensitivity to visual imagery; developed affective perception; special knowledge in the field of fine arts; 
capacities and special abilities of perception, imagination, thought and artistic and plastic creation very developed; special artistic / artistic and plastic attitudes and attitudes; artistic and plastic vision of the world; inherited and educated selfstyled capacity as a human being of art.

\section{References}

1. Bontaş I. Pedagogie. Bucharest: All Educational S.A., 1996. 315 p.

2. Curriculum de bază. Documente reglătoare/Mî; CNCE; Vl.Guţu, Vl.Pâslaru, V.Goraş-Postică ş.a. Cimişlia: Tipcim, 1997. 69 p.

3. Curriculum şcolar. Arta plastică. Clasele V-IX/ MEŞ; CNCE. Chisinau: Cartier, 2000. $31 \mathrm{p}$.

4. Dulgheru V., Cantemir L., Carcea M. Manual de creativitate. Chisinau: Tehnica-Info, 2000. $254 \mathrm{p}$.

5. Dulgheru V., Cantemir L. Creativitatea Tehnică: Ghid practic. Chisinau: Universitatea Tehnică a Moldovei, 2005. 180 p.

6. Heidegger M. Originea operei de artă. Bucharest: Univers, 1982. 390 p.

7. Jauss H. R. Experienţă estetică şi hermeneutică literară. Bucharest: Univers, 1983. $500 \mathrm{p}$.

8. Moraru I. Strategii creative transdisciplinare. Introducere în scientoeuristică. Bucharest: Editura Academiei Române, 1992. 184 p.

9. Moraru I. (coord.) Ştiinţa şi filosofia creaţiei. Fundamente euristice ale activităţii de inovare. Bucharest: EDP, R.A., 1995. 343 p.

10.Nagâţ G. Tehnici şi metode pentru stimularea creativităţii. Chisinau: Tehnica-Info, 2001. $200 \mathrm{p}$.

11.Pâslaru Vl. Valoare şi educaţie axiologică. In: Rev. Didactica Pro, 2006, nr. 1, p. 3-8

12.Pâslaru Vl. (coord.), Papuc L., Negură I. ş.a. Construcţie şi dezvoltare curriculară. Partea I. Cadrul teoretic. Chisinau: UPS Ion Creangă, 2005. 174 p. 13. Popescu G. Psihologia creativităţii. Bucharest: Fundaţiei Române de Mâine, 2004. 144 p.

14. Roco M. Creativitate şi inteligenţă emoţională. Iasi: Polirom, 2004. 245 p.

15. Roşca A. (coord.) şi colab. Creativitate, modele, programare. Studii de psihologie a gândirii. Bucureşti: Editura Ştiinţifică, 1967. 280 p.

16. Roşca A. Creativitatea generală şi specifică. Bucureşti: Editura Academiei Române, 1981. 246 p. 